\author{
Ruba Fahmi Bataineh \\ Yarmouk University \\ Shafiq Irshidat st., Irbid, Jordan \\ Qasem Mahmood Al-Kofeiri \\ Ministry of Education \\ Ramtha, Jordan
}

\title{
Morphological Awareness as a Potential Catalyst for Jordanian EFL Students' Reading Comprehension ${ }^{1}$
}

\begin{abstract}
This study examines the potential effect of morphological awareness on Jordanian EFL tenth-grade students' reading comprehension. Two intact sections of 73 Jordanian tenth-grade students were purposefully selected from a secondary school in Ramtha Directorate of Education (Ramtha, Jordan) during the first semester of the academic year 2017/2018. The experimental group $(\mathrm{n}=37)$ was taught using a morphological awarenessbased protocol whereas the control group $(n=36)$ was taught conventionally per the guidelines of the Ministry-prescribed Teacher Book of Action Pack 10. For data collection, a reading comprehension pre/post- test was used. The findings reveal a statistically significant improvement in the experimental group students' reading comprehension which may be attributed to morphological awareness-based instruction. Keywords: EFL; morphological awareness; reading comprehension
\end{abstract}

\footnotetext{
${ }^{1}$ This manuscript is an extension of the second author's doctoral dissertation per the regulations in force at Yarmouk University, Jordan.
} 
1. Introduction

Morphological awareness refers to one's ability to understand and manipulate the smallest meaningful units of language (e.g., prefixes, word roots, suffixes) to develop morphologically complex word forms (Tighe \& Schatschneider, 2015; Wolter \& Pike, 2015), or one's awareness of word structure and how it creates meaning (Stygles, 2011). Research (e.g., Mokhtari, Neel, Matatall, \& Richards, 2016, p.40) suggests that the inability to "reflect on and effectively manipulate the morphemic structure of words" is detrimental to all four language skills.

Morphological awareness may be especially essential for learners who suffer from difficulties in reading and vocabulary (Kieffer \& DiFelice Box, 2013) due to differences in the phonological and morphological structures in their native language from those in the target language (Birch, 2007; Comrie, 1989). As most English words have meanings which can be deciphered from their constituent elements (Kieffer \& DiFelice Box, 2013), not only can morphological awareness enable learners to better decode word meaning, but it can also catalyze their comprehension (Anglin, 1993; Ginsberg, Honda, \& O’Neil, 2011; Kieffer \& Lesaux, 2012b).

Reading comprehension is believed to be contingent upon a set of linguistic and cognitive capacities (Perfetti, Landi, \& Oakhill, 2005) of which morphological awareness is one (Kuo \& Anderson, 2008). Morphological awareness has been identified as a predictor of reading ability for both competent (e.g., Goodwin \& Ahn, 2013) and struggling readers (Goodwin \& Ahn, 2010) both in word decoding (e.g., Carlisle \& Stone, 2005; McCutchen, Green, \& Abbott, 2008) and comprehension (e.g., Foorman, Petscher, \& Bishop, 2012; Kieffer \& Lesaux, 2012b).

Morphological awareness has been reported to improve reading comprehension through the facilitation of word recognition fluency (McCutchen \& Logan, 2011), acceleration of the transition to making use of larger units (Saiegh-Haddad \& Geva, 2008), and fostering students' sensitivity to the morphemic structure of written words 
(Casalis, Dusautoir, Cole, \& Ducrot, 2009). Furthermore, knowledge of the meaning of derivational suffixes is believed to correlate significantly with vocabulary development and reading comprehension (Baumann, Edwards, Font, Tereshinski, Kame'enui, \& Olejnik, 2002; Parel \& Bisanz, 2007).

Building students' vocabulary repertoire and improving their reading comprehension through morphological awareness have been a major concern of EFL research (e.g. Bangs \& Binder, 2016; Carlisle, 2010; Claravall, 2016; McCutchen \& Logan, 2011). Research has demonstrated that teaching children about morphemes improves word recognition, spelling, vocabulary, and comprehension (Bowers \& Kirby, 2010; Kirk \& Gillon, 2009; Nunes \& Bryant, 2004). Thus, by infusing morphological awareness into instruction, learners are afforded a potentially viable tool not only for improving their decoding (Arnbak \& Elbro, 2000; White, Power, \& White, 1989) and language proficiency (Apel \& Werfel, 2014) but also for developing their literacy skills, raising their awareness of the morphological structure of words and affixes, and improving their vocabulary and spelling (Claravall, 2016). Research (e.g., Carlisle, 2004; Öz, 2014) suggests a positive relationship between morphological knowledge and reading comprehension, as the more learners know about morphology, the more able they are to understand new words and comprehend texts.

Research (e.g., Claravall, 2016; Goodwin \& Ahn, 2013; Hamavandi, Rezai, \& Mazdayasna, 2017; Layes, Lalonde, \& Rebaï, 2017; Zhang, 2016) also suggests that the use of morphological interventions is potentially advantageous in improving EFL learners' reading comprehension, as learners are taught to identify and analyze units of meaning (viz., roots and affixes) within words to support literacy development, since morphological awareness potentially fosters understanding and, thus, reading skills through the study of inflections, affixes, and roots. Zhang (2016), for example, claims that teaching learners to segment and extract morphological cues may help them better support their decoding, vocabulary, and reading comprehension. 
Empirical research seems to provide evidence for the effectiveness of morphological awareness in developing reading comprehension. Parel (2006), for instance, examined the effect of training in morphological analysis on 84 Canadian third-grade students' reading proficiency. Direct instruction was found to affect the acquisition of the principles of morphological analysis which, in turn, positively affected reading comprehension. Similarly, McCutchen, Logan, and Biangardi-Orpe (2009) examined the effect of morphological information on 81 fifth-grade and 82 eighth-grade students' reading comprehension. Their findings revealed that children are sensitive to word morphological structures as they read and that the use of morphological information improved reading by helping these children make sense of spelling-sound variations, decode multimorpheme words, and infer their meanings.

Stygles (2011) examined the effect of morphological word study on sixth-grade students' reading achievement. He reported that understanding roots, bases, and affixes helps students expand their lexicons to meet the requirements of vocabulary acquisition. The findings further revealed that the more students handle roots and affixes, the higher their reading achievement. Similarly, Jeon (2011) investigated the effect of morphological awareness on 188 tenth-grade Korean EFL students' reading comprehension. She reported that morphological awareness, especially derivational morphological knowledge, is indeed a significant predictor of, and catalyst for reading comprehension. In the same vein, McCutchen and Logan (2011) examined the effect of morphological awareness on 88 fifthgrade and 74 eighth-grade students' vocabulary development and reading comprehension. The findings revealed that morphological skills contribute to comprehension through facilitating word recognition fluency, vocabulary growth, and fostering comprehension of text with unfamiliar words.

Kirby, Deacon, Bowers, Izenberg, Wade-Woolley, and Parrila (2012) investigated the potential relationship between morphological awareness and reading development among 103 first- through thirdgrade children. The findings revealed that morphological awareness is 
a significant predictor of word reading accuracy, text reading speed, and reading comprehension at large. Along the same line, Deacon, Kieffer, and Laroche (2014) examined the effect of morphological awareness on 100 Canadian third- and fourth-grade students' reading comprehension. They reported findings that morphological awareness supports the development of reading comprehension by increasing children's ability to read individual words which, in turn, affects their understanding of texts.

Vaknin-Nusbaum, Sarid, and Shimron (2016) investigated the relationship between morphological awareness, word recognition, and reading comprehension among 153 second- and fifth-grade students. They reported that readers with high morphological awareness appear to have developed morphological knowledge, which, in turn, facilitates word recognition and reading comprehension.

In the Jordanian context, Al-Damiree and Bataineh (2016) examined the effect of syntactic awareness and vocabulary knowledge on the reading comprehension of 80 Jordanian ninth-grade students. They reported positive effects on both vocabulary knowledge and reading comprehension.

To conclude, morphological awareness is extremely important in terms of facilitating the understanding of vocabulary which is an essential requirement for reading comprehension. Learners increase their vocabulary by using the meanings of familiar base words and affixes to infer the meanings of unfamiliar words.

2. Problem, purpose, and significance of the study

English as a foreign language (EFL) is taught as a school subject in all Jordanian public schools starting from Grade 1. Many EFL teachers, supervisors and other practitioners report that the majority of Jordanian students have problems in English, particularly in vocabulary and reading comprehension. Research findings also report that Jordanian EFL learners' vocabulary repertoire is very limited (e.g., Al-Damiree and Bataineh, 2016; Alkhawaldeh, 2011) and, consequently, their reading comprehension ability is in dire need for improvement (e.g., Al-Barakat \& Bataineh, 2008; 2011; Al-Rabadi \& 
Bataineh, 2015; Bataineh \& Al-Barakat, 2005; 2009; Bataineh \& Alqatanani, 2017; Bataineh, Al-Rabadi, \& Smadi, 2013; Bataineh \& Al-Shorman, 2005; Bataineh \& Zghoul, 2006).

This constitutes one of numerous studies which attempt to find solutions for Jordanian students' difficulties in reading comprehension. As such, it examines the potential effect of morphological awareness-based instruction on Jordanian EFL tenthgrade students' reading comprehension. More specifically, it seeks to answer the question, are there statistically significant differences $(\alpha=$ 0.05 ) in the students' reading comprehension, which can be attributed to instruction (morphological awareness versus conventional instruction)?

This study derives its significance partly from the fact that it is, to the best of the researchers' knowledge, the first to target the Jordanian EFL context and partly from its potential contribution towards finding solutions to Jordanian students' major difficulties in reading comprehension. Moreover, the findings of the study may draw the attention of EFL teachers, in Jordan and other similar contexts, to the potential contribution of morphological awareness to reading comprehension development. EFL textbook writers and curriculum designers may also find this research of interest.

3. Method and procedures ${ }^{2}$

The participants of this study were two intact tenth-grade sections, comprising 73 Jordanian students, purposefully selected from a secondary school in Ramtha Directorate of Education during the first semester of the academic year 2017/2018. Through a coin toss, one section was randomly assigned as the control group $(n=37)$ and the other as the experimental group $(\mathrm{n}=36)$. The control group was taught conventionally according to the procedures of the Teacher Book whereas the experimental group was taught using morphological awareness-based instruction.

${ }^{2}$ Copies of the instructional program and reading comprehension test are available upon request from the authors at rubab@yu.edu.jo. 
The researchers designed a 10-week instructional program to help raise morphological awareness among the participants to potentially develop their vocabulary and reading comprehension. The activities included defining terms and using roots, suffixes, prefixes, and compounds and were supplemented by worksheets, quizzes, and tests.

The test, used as both pre- and post-test, was constructed per the General Guidelines and the Specific Outcomes of the Secondary Stage (Ministry of Education, 2006). The test, which comprises two reading comprehension texts, assesses students' reading comprehension before and after the treatment.

To ensure the validity of the instructional program and data collection instruments, they were evaluated by a jury of eleven EFL professors, supervisors, teachers, and $\mathrm{PhD}$ candidates in terms of language, content, and appropriateness for the purposes of the research. Their feedback was incorporated in the final versions of the instructional program and instruments.

To establish the reliability of the test, it was administered twice to 30 tenth-grade students, who were excluded from the main sample of the study, with a two-week interval between the two administrations. The reliability coefficient amounted to 0.82 , which is considered appropriate for the purpose of this study.

The researchers designed a four-day program (amounting to sevenand-half hours) to train the teacher of the experimental group to ensure proper implementation of the treatment.

\section{Findings and discussion}

To answer the question of the study, means and standard deviations of students' reading comprehension test scores were calculated, as shown in Table 1.

Table 1. Means and standard deviations of the students' pre- and post-test scores

\begin{tabular}{|c|c|c|c|c|c|c|c|}
\hline \multirow[b]{2}{*}{ Group } & \multirow[b]{2}{*}{$\mathrm{n}$} & \multicolumn{2}{|l|}{ Pre } & \multicolumn{2}{|l|}{ Post } & \multirow{2}{*}{$\begin{array}{l}\text { Adjusted } \\
\text { Mean }\end{array}$} & \multirow{2}{*}{$\begin{array}{l}\text { Standard } \\
\text { Error }\end{array}$} \\
\hline & & Mean & $\begin{array}{l}\text { Standard } \\
\text { Deviation }\end{array}$ & Mean & $\begin{array}{l}\text { Standard } \\
\text { Deviation }\end{array}$ & & \\
\hline
\end{tabular}




\begin{tabular}{|l|l|l|l|l|l|l|l|}
\hline Control & 36 & 5.91 & 4.34 & 8.44 & 4.75 & 8.26 & 0.47 \\
\hline Experimental & 37 & 5.43 & 4.23 & 12.10 & 3.59 & 12.28 & 0.47 \\
\hline
\end{tabular}

Table 1 reveals observed differences in the mean scores of the experimental and control groups on both the pre- and post-tests. Table 1 also shows a difference between the adjusted mean scores of the experimental and control groups. To determine whether the differences in the post-test scores bear any statistical significance (at $\alpha$ $=0.05$ ), analysis of co-variance (ANCOVA) was used (simultaneously controlling for the effect of the pre-test), as shown in Table 2.

Table 2. ANCOVA of the students' scores on the reading comprehension post-test

\begin{tabular}{|l|c|l|c|l|l|l|}
\hline Source & $\begin{array}{l}\text { Sum of } \\
\text { Squares }\end{array}$ & $\mathrm{df}$ & Mean Squares & $\mathrm{f}$ & Sig. & $\eta 2$ \\
\hline Way & 292.89 & 1 & 292.89 & 35.61 & $0.000^{*}$ & 0.33 \\
\hline Error & 575.64 & 70 & 8.22 & & & \\
\hline $\begin{array}{l}\text { Corrected } \\
\text { total }\end{array}$ & 1501.37 & 72 & & & & \\
\hline
\end{tabular}

Table 2 shows a significant difference (at $\alpha=0.05$ ) in the participants' reading comprehension post-test scores in the control and experimental groups, in favor of the latter. The participants of the experimental group outperformed their counterparts in the control group, which may be attributed to the type of instruction.

The instructional program comprised a variety of reading passages which focused on affixed words, which may have helped the participants of the experimental group learn these words in context (rather than in isolation). By extension, understanding the new vocabulary may have helped the participants to better understand the meaning of the text itself.

The instructional program allowed the participants multiple opportunities for practice which raised their morphological awareness and, in turn, resulted in better reading comprehension. Not only were 
the reading texts carefully chosen to suit the students' level and interests, but they were also taught with focus on morphological awareness. Consequently, the participants were constantly alert to morphological markers which enabled them to better decode otherwise difficult words to comprehend the reading texts.

To reiterate, the superiority of the performance of the experimental group can be attributed to several factors. First, not only did the teacher, who taught the group, receive intensive four-day training on both morphological awareness and implementing the instructional program, but he also received continuous support through weekly meetings with the researchers. Second, the participants engaged actively in learning through carefully designed activities in a nonthreatening atmosphere over a period of ten weeks. Third, the novelty of the treatment may have given the participants an extra incentive to learn away from the monotony of traditional instruction.

These findings are consistent with those reported in the literature (e.g., Carlisle \& Stone, 2005; Crosson \& Moore, 2017; Hamavandi et al., 2017) which suggest that morphological awareness potentially contributes to reading comprehension by supporting the interpretation of unknown words. The current findings are also consistent with reading research, which considered morphological awareness a catalyst for developing decoding and reading comprehension (Carlisle, 2004; Layes et al., 2017; Kirby et al., 2012; Kuo \& Anderson, 2006; Zhang, 2016) and word knowledge (Kirby et al., 2012).

5. Conclusions, implications, limitations and recommendations Morphological awareness has been reported as a catalyst to language learning in general and vocabulary development and reading comprehension in particular. Morphological instruction is potentially indispensable for language learners who need to recognize and manipulate new words (Graves, 2006; Kieffer \& Lesaux, 2012a, 2012b), as familiarity with word formation (through prefixes, suffixes and roots) may facilitate decoding and text comprehension (Kieffer \& DiFelice Box, 2013). 
Morphological awareness has been linked not only to reading comprehension but also to literacy development (Liu \& McBrideChang, 2010), as better reading comprehension often culminates in improved writing skills (Kieffer \& DiFelice Box, 2013). Carlisle (2003) goes as far as claiming that reading cannot succeed if the reader does not appreciate morphological word formation, as morphological awareness potentially enables learners to break down words into their constituent elements, which may translate into better understanding and, ultimately, facilitated learning.

This, coupled with findings that the meaning of 60 percent of unknown words in texts can be predicted from their morphemes (Nagy $\&$ Anderson, 1984) and that learners who understand how words are created from joining suffixes, prefixes, and roots have a richer vocabulary repertoire (Kieffer \& Lesaux, 2012a), may constitute evidence for the utility of morphological awareness in the foreign language classroom. Following the lead of the current research, teachers may adopt an explicit approach to raising learners' morphological awareness not only by making morphology (e.g., breaking words into constituent morphemes) part of their instructional routines but also by teaching how new words are formed by means of prefixes, affixes and roots.

The current findings have corroborated previous ones that morphological awareness is a catalyst for reading comprehension. The treatment has brought about a marked improvement in the participants' reading comprehension. However, the little effect of the treatment on developing the participants' reading comprehension may be attributed to that Jordanian students are reported to face substantial difficulties in reading comprehension (e.g., Al-Damiree \& Bataineh, 2016) as a result of insufficient grasp over vocabulary and complex grammatical structures. Moreover, ten weeks, albeit sufficient for the purposes of this research, may be too short to notice marked improvement in the participants' reading comprehension.

Thus, EFL teachers are recommended to incorporate morphological awareness in their reading comprehension instruction. The Ministry of Education, textbook writers, and syllabus designers 
are also called upon to incorporate morphological awareness into Jordanian EFL textbooks. Finally, researchers are recommended to extend the scope of this research to encompass other skills, such as spelling and writing, over a longer time interim.

\section{References}

Al-Barakat, A. A., \& Bataineh, R. F. (2008). Jordanian student teachers' use of computers to develop primary stage pupils' literacy skills. International Journal of Educational Development Using ICT, 4(4), 64-87.

Al-Barakat, A. A., \& Bataineh, R. F. (2011). Preservice childhood education teachers' perceptions of instructional practices for developing young children's interest in reading. Journal of Research in Childhood Education, 25(2), 177-193.

Al-Damiree, R.R., \& Bataineh, R. F. (2016). Vocabulary knowledge and syntactic awareness as potential catalysts for reading comprehension among young Jordanian EFL students. Journal of Teaching and Teacher Education, 4(1), 53-59.

Alkhawaldeh, A. (2011). EFL reading comprehension interests among Jordanian high school students and their relationship with gender achievement level and academic stream. European Journal of Social Sciences, 23(3), 454-465.

Al-Rabadi, R. Y., \& Bataineh, R. F. (2015). Learning strategies in literature-based instruction: A qualitative study of Jordanian university students. Journal of Teaching and Teacher Education (University of Bahrain), 3(1), 101-110.

Anglin, J. M. (1993). Vocabulary development: A morphological analysis. Monographs of the Society for Research in Child Development, 58(10), 1-166.

Apel, K., \& Werfel, K. (2014). Using morphological awareness instruction to improve written language skills. Language, Speech and Hearing Services in Schools, 45(4), 251-260.

Arnbak, E., \& Elbro, C. (2000). The effects of morphological awareness training on the reading and spelling skills of young dyslexics. Scandinavian Journal of Educational Research, 44(3), 229-251.

Bangs, K., \& Binder, K. (2016). Morphological awareness intervention: Improving spelling, vocabulary, and reading comprehension for adult learners. Journal of Research and Practice for Adult Literacy, Secondary and Basic Education, 5(1), 49-56.

Bataineh, R. F., \& Al-Barakat, A. A. (2005). ihtimãmãt ul-qirã?a wa-mu3awiqatuha lada tala:mi: $\delta$ aș-șufu:f al-asãsiya a $\theta-\theta$ alã $\theta$ a al-?u:la fi: mudi:riyãt at-tarbiya watta3li:m fi: mantiqat famãl il-urdun (The reading interests of Jordanian first-, second-, and third-grade pupils and the obstacles limiting these interests). Journal of Educational and Psychology Sciences, 6(3), 107-133. 
Bataineh, R. F., \& Al-Barakat, A. A. (2009). Jordanian early primary stage teachers' self-reported practices to develop their pupils' reading in Arabic. Mediterranean Journal of Educational Studies, 14(2), 65-92.

Bataineh, R. F., \& Alqatanani, A. K. (July 2017). The effect of a thinking maps-based instructional program on Jordanian EFL tenth-grade students' critical reading skills. Asian EFL Journal, 101(2), 31-61.

Bataineh, R. F., \& Al-Shorman, R. A. (2005). Jordanian EFL university students' reading interests. Abhath Al-Yarmouk (Humanities and Social Sciences Series), 21(3a), 35-56.

Bataineh, R. F., \& Zghoul, L. H. (2006). Jordanian TEFL graduate students' use of critical thinking skills (as measured by the Cornell Critical Thinking Test, Level Z). International Journal of Bilingual Education and Bilingualism, 9(1), 33-50.

Bataineh, R. F., Al-Rabadi, R. Y., \& Smadi, O. M. (2013). Fostering Jordanian university students' communicative performance through literature-based instruction. The TESOL Journal, 4(4), 655-673.

Baumann, J. F., Edwards, E. C., Font, G., Tereshinski, C. A., Kame'enui, E. J., \& Olejnik, S. (2002). Teaching morphemic and contextual analysis to fifth-grade students. Reading Research Quarterly, 37(2), 150-176.

Birch, B. (2007). English L2 Reading: Getting to the Bottom. Mahwah, New Jersey: Lawrence Erlbaum.

Bowers, P., \& Kirby, J. (2010). Effects of morphological instruction on vocabulary acquisition. Reading and Writing, 23, 515-537.

Carlisle, J. F. (2003). Morphology matters in learning to read: A commentary. Reading Psychology, 24(3-4), 291-322.

Carlisle, J. F. (2010). Effects of instruction in morphological awareness on literacy: An integrative review. Reading Research Quarterly, 45(4), 464-487.

Carlisle, J. F. (2004). Morphological processes influencing literacy learning. In C. Stone, E. Silliman, B. Ehren, \& K. Apel (Eds.), Handbook on Language and Literacy: Development and Disorders (pp. 318-339). New York: Guilford.

Carlisle, J. F., \& Stone, C. A. (2005). Exploring the roles of morphemes in word reading. Reading Research Quarterly, 40(4), 428-449.

Casalis, S., Dusautoir, M., Cole, P., \& Ducrot, S. (2009). Morphological effects in children word reading: A priming study in fourth graders. British Journal of Developmental Psychology, 27(3), 761-766.

Claravall, E. (2016). Integrating morphological knowledge in literacy instruction: Framework and principles to guide special education teachers. Teaching Exceptional Children, 48(4),195-203.

Comrie, B. (1989). Language Universals and Linguistic Typology: Syntax and Morphology. Oxford: Blackwell. 
Crosson, A. C., \& Moore, D. (2017). When to take up roots: The effects of morphology instruction for middle school and high school English learners. Reading Psychology, 38(3), 262-288.

Deacon, H., Kieffer, M., \& Laroche, A. (2014). The relation between morphological awareness and reading comprehension: Evidence from mediation and longitudinal models. Scientific Studies of Reading, 18(6), 432-451.

Foorman, B. R., Petscher, Y., \& Bishop, M. D. (2012). The incremental variance of morphological knowledge to reading comprehension in grades 3-10 beyond prior reading comprehension, spelling, and text. Learning and Individual Differences, 22(6), 792-798.

Ginsberg, D., Honda, M., \& O’Neil, W. (2011). Looking beyond English: Linguistic inquiry for English language learners. Language and Linguistics Compass, 5(5), 249-264.

Goodwin, A. P., \& Ahn, S. (2010). A meta-analysis of morphological interventions: Effects on literacy achievement of children with literacy difficulties. Annals of Dyslexia, 60(2), 183-208.

Goodwin, A. P., \& Ahn, S. (2013). A meta-analysis of morphological interventions in English: Effects on literacy outcomes for school-age children. Scientific Studies of Reading, 17(4), 257-285.

Graves, M. F. (2006). The Vocabulary Book: Learning and Instruction. New York: Teachers College Press.

Hamavandi, M., Rezai, M., \& Mazdayasna, G. (2017). Dynamic assessment of morphological awareness in the EFL context. Cogent Education, 4: 1324254. $\begin{array}{lllll}\text { Retrieved } & 31 & \text { March } & 2018 & \text { from }\end{array}$ https://www.tandfonline.com/doi/full/10.1080/2331186X.2017.1324254.

Jeon, E. (2011). Contribution of morphological awareness to second-language reading comprehension. Modern Language Journal, 95(2), 217-235.

Kieffer, M. J., \& DiFelice Box, C. (2013). Derivational morphological awareness, academic vocabulary, and reading comprehension in linguistically diverse sixth graders. Learning and Individual Differences, 24, 168-175.

Kieffer, M. J., \& Lesaux, N. K. (2012a). Development of morphological awareness and vocabulary knowledge in Spanish-speaking language minority learners: A parallel process latent growth curve model. Applied Psycholinguistics, 33(1), 2354.

Kieffer, M. J., \& Lesaux, N. K. (2012b). Direct and indirect roles of morphological awareness in the English reading comprehension of native English, Spanish, Filipino, and Vietnamese speakers. Language Learning, 64(4), 1170-1204.

Kirby, J., Deacon, H., Bowers, P., Izenberg, L., Wade-Woolley, L., \& Parrila, R. (2012). Children's morphological awareness and reading ability. Reading and Writing, 25(2), 389-410. 
Kirk, C., \& Gillon, G. (2009). Integrated morphological awareness intervention as a tool for improving literacy. Language, Speech and Hearing Services in Schools, 40(3), 341-351.

Kuo, L.-J., \& Anderson, R. C. (2008). Conceptual and methodological issues in comparing meta linguistic awareness across languages. In K. Koda \& A. Zehler (Eds.), Learning to Read across Languages (pp. 39-67). New York: Routledge.

Layes, S., Lalonde, R., \& Rebaï, M. (2017). Study on morphological awareness and rapid automatized naming through word reading and comprehension in normal and disabled reading Arabic-speaking children. Reading and Writing Quarterly, 33(2), 123-140.

Liu, P. D., \& McBride-Chang, C. (2010). What is morphological awareness? Tapping lexical compounding awareness in Chinese third graders. Journal of Educational Psychology, 102(1), 62-73.

McCutchen, D., Green, L., \& Abbott, R. D. (2008). Children's morphological knowledge: Links to literacy. Reading Psychology, 29(4), 289-314.

McCutchen, D., \& Logan, B. (2011). Inside incidental word learning: Children's strategic use of morphological information to infer word meanings. Reading Research Quarterly, 46(4), 334-349.

McCutchen, D., Logan, B., \& Biangardi-Orpe, U. (2009). Making meaning: Children's sensitivity to morphological information during word reading. Reading Research Quarterly, 44(4), 360-376.

Ministry of Education (2006). The General Guidelines and General and Specific Outcomes for the English Language Basic and Secondary Stages. Amman (Jordan): Directorate of Curricula and School Textbooks.

Mokhtari, K., Neel, J., Matatall, A., \& Richards, A. (2016). The contribution of morphological knowledge to 7th grade students' reading comprehension performance. Reading Horizons, 55(1), 39-57. Retrieved 31 March 2018 from https://scholarworks.uttyler.edu/education fac/6/.

Nagy, W. E., \& Anderson, R. C. (1984). How many words are there in printed school English? Reading Research Quarterly, 19, 304-330.

Nunes, T., \& Bryant, P. (2004). Morphological awareness improves spelling and vocabulary. Literacy Today, 38, 18-19.

Öz, H. (2014). Morphology and implications for English language teaching. In A. Saricoban (Ed.), Linguistics for English Language Teaching Studies (pp. 83-120). Ankara: Ani Publishing.

Parel, R. (2006). The impact of training in morphological analysis on literacy in the primary grades. International Journal of Learning, 13(4), 119-128.

Parel, R., \& Bisanz, G. (2007). Sensitivity to word structure: The relationship of knowledge of derivational suffixes to reading proficiency in grades one and two. International Journal of Learning, 14(4), 135-144. 
Perfetti, C.A., Landi, N., \& Oakhill, J. (2005). The acquisition of reading comprehension skill. In M. J. Snowling \& C. Hulme (Eds.), The Science of Reading: A Handbook (pp. 227-247). Oxford: Blackwell.

Saiegh-Haddad, E., \& Geva, E. (2008). Morphological awareness, phonological awareness, and reading in English-Arabic bilingual children. Reading and Writing, 21(5), 481-504.

Stygles, J. (2011). Implementing morphological word study in the intermediate classroom. New England Reading Association Journal, 46(2), 60-66.

Tighe, E., \& Schatschneider, C. (2015). Exploring the dimensionality of morphological awareness and its relations to vocabulary knowledge in adult basic education students. Reading Research Quarterly, 50(3), 293-311.

Vaknin-Nusbaum, V., Sarid, M. \& Shimron, J. (2016). Morphological awareness and reading in second and fifth grade: Evidence from Hebrew. Reading and Writing. 29(2), 229-244.

White, T., Power, M., \& White, S. (1989). Morphological analysis: Implications for teaching and understanding vocabulary growth. Reading Research Quarterly, 24, 283-304.

Wolter, J., \& Pike, K. (2015). Dynamic assessment of morphological awareness and third-grade literacy success. Language, Speech and Hearing Services in Schools, 46(2), 112-126.

Zhang, H. (2016). Does morphology play an important role in L2 Chinese vocabulary acquisition? Foreign Language Annals, 49(2), 384-402. 